\title{
Entry, Dispersion and Differentiation of Microglia in the Developing Central Nervous System*
}

\author{
JULIO NAVASCUÉS, RUTH CALVENTE, \\ JOSÉ L. MARÍN-TEVA ${ }^{1}$ and MIGUEL A. CUADROS \\ Departamento de Biología Celular, Facultad de Ciencias, \\ Universidad de Granada, E-18071 Granada, Spain
}

Manuscript received on December 17, 1999; accepted for publication on December 19, 1999

\begin{abstract}
Microglial cells within the developing central nervous system (CNS) originate from mesodermic precursors of hematopoietic lineage that enter the nervous parenchyma from the meninges, ventricular space and/or blood stream. Once in the nervous parenchyma, microglial cells increase in number and disperse throughout the CNS; these cells finally differentiate to become fully ramified microglial cells. In this article we review present knowledge on these phases of microglial development and the factors that probably influence them.
\end{abstract}

Key words: microglia, hematopoietic lineage, meninges, migration, proliferation.

\section{INTRODUCTION}

The early origin of microglial cells is still a controversial subject (Cuadros \& Navascués 1998). Some authors sustain that microglial cells originate from precursors of neuroepithelial origin that can also give rise to other glial cell types (Hao et al. 1991, Fedoroff 1995, Fedoroff et al. 1997). However, the most widespread view is that microglial cells derive from mesodermal cells (likely of hematopoietic lineage) that invade the nervous parenchyma (Perry \& Gordon 1991, Ling \& Wong 1993, Cuadros \& Navascués 1998, Stoll \& Jander 1999, Wilms et al. 1999).

The processes involved in the establishment of the microglial population during central nervous system (CNS) development differ from those re-

\footnotetext{
*Invited paper

Correspondence to:

Dr. Julio Navascués, navascue@goliat.ugr.es

${ }^{1}$ Present address: INSERM U.495, Hôpital de la Salpêtrière,47

Boulevard de l'Hôpital, 75651 Paris Cedex 13, France
}

sponsible for microglial turnover and the microglial response to pathological conditions in the adult CNS. Presumably, different mechanisms operate in both phenomena and without further verification it is not possible to apply insights obtained in the adult or postnatal brain to the less mature embryonic nervous tissue. In the latter, the constitution of the microglial cell population involves several steps: (1) entry of microglial precursors from outside the nervous system; (2) dispersion of microglial cells throughout the nervous parenchyma; and (3) differentation of microglial cells. This review will discuss each one of these steps.

\section{ENTRY OF MICROGLIAL PRECURSORS INTO THE DEVELOPING CNS}

As noted above most authors believe that microglial precursors originate from cells outside the nervous tissue. These cells have to enter the CNS. When and how do these cells enter the developing nervous tissue? A great increase in the number of microglial 
cells is detected within the developing CNS of avian embryos (chick and quail) during the second half of the incubation time (Navascués et al. 1996, Cuadros \& Navascués 1998). Increases in the number of such cells have also been described in rodents during the last days of embryonic life and first days of postnatal life (Milligan et al. 1991, Perry \& Gordon 1991). Observations made at these times suggest that microglial precursors use several ways of entry. The first way is from the meninges, by traversing the pial surface. Putative microglial precursors accumulate at some points on both sides of the pial surface (RioHortega 1932, Boya et al. 1991, Perry \& Gordon 1991, Cuadros \& Navascués 1998); many microglial precursors probably enter the nervous parenchyma at these points. In addition to the entry of large numbers of microglial precursors at particular points, isolated cells seem to traverse the pial surface at other locations. The second way of entry of microglial precursors into the nervous parenchyma is from the ventricles, by squeezing between the neuroepithelial cells that line them. In the third way, some circulating blood cells, which would be microglial precursors, leave vessels within the nervous parenchyma by traversing the endothelial wall. It seems that most microglial precursors come from the meninges and the ventricular lumen during embryonic development, and that entry from the blood stream becames more frequent in more mature animals. In the adult brain, which shows features different from those of the developing one, most of the microglial precursors responsible for microglial turnover and response to injury probably enter the CNS from the blood stream.

It is reasonable to think that special features in the embryo favour the nervous parenchyma invasion. First, the number of microglial precursors may be higher at embryonic and early postnatal stages, when is thought that most of microglial precursors enter, than at the adult stage. Second, the entry of these precursors may be easier when the CNS is not yet mature, since the blood-brain barrier is not fully developed until several days after hatching in the chick (Stewart \& Wiley 1981) or two weeks after birth in the rat (Xu et al. 1993), after which time most microglial precursors have already entered the CNS.

In addition to these special features, specific factors are likely involved in the recruitment of microglial precursors for entry into the embryonic CNS. Some factors may be released as consequence of phenomena observable at microscopic level, such as cell rearrangements or cell death. Cytokines such as the monocyte chemoattractant protein-1 (MCP1) recruit monocytes and other leukocytes from the blood stream after injury (Glabinski et al. 1996, Mallat et al. 1996, Ivacko et al. 1997). The role of these and/or other molecules in recruiting microglial precursors during development has yet to be established.

\section{DISPERSION OF MICROGLIAL PRECURSORS WITHIN THE CNS}

Once inside the nervous parenchyma, microglial precursors colonize the CNS by two mechanisms: migration and proliferation.

\section{Migration of Ameboid Microglial Cells}

Microglial cells become distributed throughout the entire CNS (Perry et al. 1985, Lawson et al. 1990) by migration of microglial precursors through the nervous parenchyma (Schnitzer 1989; Pearson et al. 1993, Cuadros et al. 1994, 1997, Navascués et al. 1995, Wolswijk 1995, Marín-Teva et al. 1998) from their entry at definite "hot spots" on the pial or ventricular surfaces. If microglial precursors are recruited into the nervous parenchyma directly from circulating blood, they could easily reach their final locations in the CNS by extravasation at these sites. The fact that regions of high microglial cell density in the mature CNS do not appear to be related to the sites of entry of microglial precursors into the brain during development (Perry \& Gordon 1991) suggests that extensive migration of microglial precursors occurs during development.

Studies in developing vertebrates have documented long-distance migration of microglial ameboid cells in several CNS regions such as the retina 
(Navascués et al. 1995, Diaz-Araya et al. 1995a, 1995b), optic tectum (Cuadros et al. 1994) and cerebellum (Cuadros et al. 1997). Microglial ameboid cells in these regions with layered cytoarchitectonic patterns do not migrate at random but use definite routes to reach their final destinations. Studies of quail CNS serial sections taken at one-day intervals throughout development reveal the existence of two phases in the microglial migration. During the first phase, called tangential migration, ameboid microglial cells migrate parallel to the CNS surface to spread through the full extent of a single layer in each CNS region. In the second phase, microglial cells change their direction to move perpendicularly from the layer in which they migrated tangentially, thus gaining access to different depths in the nervous parenchyma. This phase is called radial migration.

\section{TAngential Migration}

Tangential migration of ameboid microglial cells takes place on the end-feet of Müller cells and along the nerve fiber layer in the retina (Navascués et al. 1995, Marín-Teva et al. 1998), through the stratum album centrale in the optic tectum (Cuadros $e t$ al. 1994), and along the developing white matter in the cerebellum (Cuadros et al. 1997). All these regions have axonal fascicles which run tangentially for long distances and pass near the "hot spots" of entry of microglial precursors at some point along their length. Thus, long axonal tracts appear to be oriented pathways used by ameboid microglial cells to spread through the CNS from their entry points.

Several studies have dealt with the mechanism of migration of ameboid microglia within the CNS. Some of them are in vitro approaches to this issue (Booth \& Thomas 1991, Ward et al. 1991, Abd-ElBasset \& Fedoroff 1995, Haapaniemi et al. 1995, Brockhaus et al. 1996) but only one (Marín-Teva et al. 1998) has shed light on mechanisms involved in long migrations of ameboid microglia in situ. This study showed that the most conspicuous morphological feature of ameboid microglial cells migrating in the vitrealmost part of the developing quail retina is their flattened morphology, with extensive lamellipodia emerging either from the cell body or from cell processes of variable length and closely adhering to the substrate. Nevertheless, these cells had a changing morphology allowing their classification in different morphological types, some of them clearly polarized in the direction of their movement. Analysis of these cell types suggested that the mechanism of migration of ameboid microglia in the developing quail retina includes stages of locomotion similar to those of fibroblasts in culture. These stages consist of the polarized extension of lamellipodia at the leading edge of the cell, strong cell-to-substrate anchorage, translocation of the cell body forward, and retraction of the rear of the cell. Cell-to-substrate anchorage includes two types of attachments: attachments of the lateral surface of both lamellipodia and cell bodies to Müller cell radial processes, and attachments of the vitreal face of the cell (cell body and processes) to the underlying basal lamina through gaps in the carpet of Müller cell end-feet. Morphological evidence of retraction of the rear of the cell is the presence of very thin thread-like processes of variable length projecting from some migrating ameboid microglial cells; strong cell-to-substrate attachments in the trailing part of the cell would offer resistance to cell retraction, giving rise to such thread-like processes.

Non-polarized cells with lamellipodial projections from the cell body radiating in all directions are present in the population of migrating ameboid microglial cells of the developing quail retina, suggesting that microglial cells explore the surrounding environment to orient their movement (MarínTeva et al. 1998). During the orientation phase, lamellipodia seem to function as devices for exploring the substrate and recognizing signals that help determine the direction of ameboid microglial cell movement.

When sheets containing the inner limiting membrane covered by a carpet of Müller cell end-feet are obtained from the vitrealmost part of the developing retina many ameboid microglial cells remain attached on them (Marín-Teva et al. 1998, 1999b) demonstrating that they use the Müller cell end-feet 
as a substrate for tangential migration. Müller cell end-feet form grooves flanked by rows of Müller cell radial processes that are oriented in the same direction as the tangential movement of ameboid microglial cells. In fact, two types of tangential migration of microglial cells occur in the quail retina: central-to-peripheral migration from the optic nerve head (Navascués et al. 1995, Marín-Teva et al. 1998) and circumferential migration in the margin of the retina (Marín-Teva et al. 1999b). The orientation of the substrate in nonmarginal areas is different from that in the margin of the retina and cell migration follows the orientation of the substrate in each area. This correspondence suggests that mechanical guidance is involved in the tangential migration of ameboid microglia through the retina. In addition to their role in the mechanical guidance of ameboid microglial cells, Müller cell end-feet may also participate in their adhesive guidance, because adhesion molecules such as N-CAM and laminin are present on Müller cell end-feet of the developing chick and quail retina (Halfter et al. 1987, Halfter \& Fua 1987).

Müller cell end-feet form a laminar substrate on which ameboid microglial cells migrate in the retina. In contrast, ameboid microglia migrating in other regions of the CNS move in non-laminar environments made of axonal fascicles. Can knowledge on microglial migration obtained from the retina model be extrapolated to other parts of the CNS? We think so, because ameboid microglial cells migrating along axonal fascicles show morphological features similar to those migrating on Müller cell end-feet, i.e. they have a cell body sending out pseudopodia, lamellipodia and occasional filopodia (Rio-Hortega 1932, Ling 1976, Boya et al. 1979, 1991, Ling et al. 1980, Murabe \& Sano 1982, Perry et al. 1985, Ashwell 1990, Cuadros et al. 1994, 1997, Brockhaus et al. 1996, Moujahid et al. 1996) and show close contacts with axons (Navascués et al. 1996). The only difference appears to be that ameboid microglial cells are flattened in the retina while they are rounded in axonal tracts as a result of the non-laminar environment.

\section{RADial MigRation}

Radial migration of ameboid microglial cells has been reported to occur in the retina (Navascués et al. 1995), the optic tectum (Cuadros et al. 1994), and the cerebellum (Cuadros et al. 1997) of the quail embryo. In the optic tectum and the cerebellum, ameboid microglia migrate radially towards the pial surface from the stratum album centrale and the white matter, respectively. In the retina, they move from the vitrealmost part, where they were migrating tangentially, towards scleral levels. As a consequence, ameboid microglial cells reach different layers in these CNS parts where they subsequently differentiate. During development of the CNS in rodents, ameboid microglia are first seen in the white matter and then in the gray matter (Perry et al. 1985) suggesting that radial migration through the gray matter also occurs in mammals.

In the quail developing retina, some QH1labeled ameboid microglial cells are oriented perpendicularly to the vitreal surface of the retina and adhere to the radial cell processes of Müller cells, suggesting that they use radially oriented Müller glia as a substrate for radial migration (Navascués et al. 1996). Other radially oriented glial cells, such as radial glia in the optic tectum or Bergman glia in the cerebellar cortex, might also guide radial microglial migration in these parts of the CNS. Our group detected rows of QH1-labeled ameboid microglial cells on the wall of radially-oriented vessels in the developing brain stem of the quail, strongly suggesting that these microglia are in the process of radial migration along the vessel walls (Navascués et al. 1996). The optic tectum and the cerebellar cortex also have a system of radially-oriented blood vessels which might provide a substrate for microglial migration.

Radial migration of ameboid microglial cells in the quail retina occurs in two phases (Marín-Teva et al. 1999c). During the first phase, microglial cells migrate along the nerve fiber layer and the ganglion cell layer to reach the vitreal border of the inner plexiform layer. In the second phase, they mi- 
grate across the inner plexiform layer and the inner nuclear layer to gain access to the outer plexiform layer. This second phase occurs after a stopover of several days at the vitreal border of the inner plexiform layer that may be related to synaptogenesis in the inner plexiform layer. We do not know whether similar microglial cell stopovers take place during radial migration in other parts of the CNS.

\section{Neuronal Apoptosis and Microglial Cell Migration}

The fact that ameboid microglial cells migrate in a stereotyped manner suggests that migration is controlled by specific factors present in the developing CNS. The nature of such factors is not known at present although limited knowledge can be extrapolated from experimental studies in the injured adult brain or from in vitro studies. Thus, chemokines such as MCP-1, macrophage inflammatory protein or fractalkine induce migration and reorganization of the actin cytoskeleton in adult microglia in vitro (Badie et al. 1999; Cross \& Woodroofe 1999, Maciejewski-Lenoir et al. 1999). Some of these chemokines are released in the injured immature brain (Ivacko et al. 1997) but their influence on the migration of ameboid microglial cells in the developing normal CNS has not been determined.

It has been proposed that naturally occurring neuronal death attracts microglial cells in the developing CNS. Therefore, factors released from dying neurons would promote the migration of ameboid microglia. This hypothesis is supported by the chronologic coincidence of neuronal death with the entry of microglial precursors into the nervous parenchyma (Hume et al. 1983, Perry et al. 1985, Perry 1987, Schnitzer 1989, Ashwell 1990, 1991, Perry \& Gordon 1991, Pearson et al. 1993). In addition, a close physical association between dying neurons and microglial cells is frequently observed in the developing nervous parenchyma (Wong \& Hughes 1987, Ashwell 1990, 1991, Ferrer et al. 1990, Milligan et al. 1991, Thanos 1991, Thanos et al. 1996, Ashwell \& Bobryshev 1996, Egensperger et al. 1996, Moujahid et al. 1996). However, this hypothesis is contradicted by the entry of microglial precursors into mammalian retina well before the period of neuronal death (Ashwell 1989, Ashwell et al. 1989, Diaz-Araya et al. 1995b) and by the absence of microglia in some areas of the brain where cell death is present (Milligan et al. 1991, Rakic \& Zecevic 1998). In the developing quail retina model, the chronology of entry and tangential migration of ameboid microglial cells is highly coincident with that of cell death in the ganglion cell layer (MarínTeva et al. 1999c). However, microglial cells migrate tangentially on Müller cell end-feet (MarínTeva et al. 1998) and there is no colocalization between them and dying ganglion cell bodies, suggesting that the tangential migration of microglial cells is not directly related to neuronal death in the ganglion cell layer. A similar conclusion was drawn in a recent study on rat retina (Garcia-Valenzuela \& Sharma 1999) that showed that macrophages invade the nerve fiber layer of the retina after optic nerve axotomy but do not enter into the ganglion cell layer or more scleral layers despite massive ganglion cell death. Nevertheless, it cannot be ruled out that axons of dying ganglion cells transmit signals favoring the migration of microglial cells in contact with them. In summary, the hypothesis that ganglion cell death triggers tangential migration in the developing quail retina is controversial. In contrast, a recent study (Marín-Teva et al. 1999c) clearly demonstrated that cell death in the inner nuclear layer does not stimulate radial migration of ameboid microglial cells in the quail retina. In fact, microglial cells do not appear to be attracted by dying cells in the inner nuclear layer during their stopover for two or three days at the vitreal border of the inner plexiform layer. On the contrary, microglial cells traverse the inner nuclear layer only after cell death has ceased in this layer, as also occurs after experimentally induced neuronal death in the lizard medial cortex (LópezGarcía et al. 1994).

\section{Proliferation of Ameboid Microglial Cells}

Ramified microglia in the adult CNS proliferate at a slow rate (Perry \& Gordon 1991, Lawson et al. 
1992, Perry \& Lawson 1992) that dramatically increases upon activation (Streit et al. 1988, Gehrmann et al. 1995). Proliferative activity of ameboid microglia also occurs during normal development in the vertebrate CNS (Ling 1981, Ling \& Wong 1993) as shown by reports on mitotic ameboid microglial cells (Ling \& Tan 1974, Schnitzer 1989, Kaur \& Ling 1991, Wu et al. 1996). This activity has also been deduced from autoradiographic studies (Imamoto \& Leblond 1978, Kitamura et al. 1984) in the developing corpus callosum of postnatal rats, and from expression of the proliferating cell nuclear antigen (PCNA) in ameboid microglial cells in the embryonic retina of the quail (Marín-Teva et al. 1999a), in the hippocampus and cerebral cortex of embryonic and postnatal rats (Dalmau 1997), and in the white matter of the developing spinal cord in the jimpy mouse (Vela-Hernández et al. 1997).

Our recent study on the developing quail retina (Marín-Teva et al. 1999a) has shown that migrating ameboid microglial cells enter mitosis. As mitosis advances, microglial cells retract their lamellipodia and become rounded, transiently stopping migration while they go through metaphase, anaphase and early telophase. Before completion of cytokinesis, daughter cells again extend lamellipodia to resume migration. Thus, ameboid microglial cells go through cycles in which migration and mitosis alternate. Cell division of microglial precursors has been also reported to occur in other locations where these precursors are actively migrating (Rio-Hortega 1932), such as the white matter of the developing quail cerebellum (Cuadros et al. 1997) and the developing rat corpus callosum (Ling \& Tan 1974, Kaur \& Ling 1991, Wu et al. 1996). Therefore, proliferation of ameboid microglia during their migration appears to be a widespread event that contributes to an increase in the number and dispersion of microglial precursors through the CNS during normal development.

Interestingly, the mitotic index of ameboid microglial cells migrating tangentially in the developing retina is high during the early migration of these cells and decreases progressively as development advances (Marín-Teva et al. 1999a). These results suggest that the proliferation rate of ameboid microglia diminishes with development and becomes very low when differentiation occurs, in agreement with the very slow rate of proliferation of mature microglia (Perry \& Gordon 1991, Lawson et al. 1992, Perry \& Lawson 1992).

Migration/mitosis cycles influence the migratory behavior of ameboid microglia (Marín-Teva et al. 1999a) because both daughter microglial cells resume movement before completion of cytokinesis, and therefore before the centrosome of the trailing daughter cell can migrate toward the opposite cell pole. Thus, one daughter cell continues to migrate in the same direction as before entering mitosis, while the other moves transiently in the opposite direction and then turns back (Marín-Teva et al. 1998, 1999a).

Proliferation of ameboid microglia is probably controlled by a variety of factors such as the colony stimulating factors (CSF) GM-CSF and CSF1 (Giulian \& Ingemann 1988, Sawada et al. 1990, Suzumura et al. 1990, Ganter et al. 1992, ShafitZagardo et al. 1993, Lee et al. 1994, Suzumura \& Sawada 1996, Liva et al. 1999), two microglial mitogens with molecular masses of 50 and $22 \mathrm{kD}$ (Giulian et al. 1991), neurotrophin-3 (Elkabes et al. 1996), interleukin-4 (Suzumura et al. 1994) and interleukin-5 (Ringheim 1995). These factors have been demonstrated to be present in the CNS during development when ameboid microglia are also present. The influence of these factors on microglial cell proliferation has been shown in vitro but there are no experimental studies that demonstrate it in vivo . In addition, in op/op mice, which are deficient in CSF-1, the number of microglia in the CNS is not affected (Berezovskaya et al. 1995) suggesting that CSF-1 has no influence on microglial proliferation during in vivo development, despite the fact that CSF-1 deficiency inhibits the normal in vitro development of microglia (Blevins \& Fedoroff 1995) and the proliferation of activated microglia after axotomy in adulthood (Raivich et al. 1994). On the other hand, other factors such as the pigment epithelium-derived factor (Sugita et al. 1997), cer- 
tain corticosteroids (Ganter et al. 1992), and adrenergic agonists (Fujita et al. 1998) have been shown to inhibit proliferation of microglia in vitro. Therefore, higher or lower proliferation of ameboid microglia during CNS development probably depends on the combined action of various stimulating and inhibiting factors. Further investigation is necessary to elucidate which factors control in vivo the proliferation of ameboid microglial cells during CNS development.

\section{DIFFERENTIATION OF MICROGLIAL CELLS}

After reaching their final location, microglial cells progressively acquire a ramified morphology, first becoming intermediate, scarcely ramified microglial cells and finally mature, fully ramified microglia. The morphological differentiation of these cells reflects the change from motile cells to quiescent cells that apparently do not move from their location. This differentiation is accompanied by changes in their immunophenotype: ramified cells are not labeled or are poorly labeled with antibodies that strongly label ameboid microglia (Milligan et al. 1991, Flaris et al. 1993, Cuadros \& Navascués 1998). The nature of the factors promoting this differentiation has been extensively studied, mostly using in vitro systems. It has been established that blood serum inhibits the acquisition of a ramified phenotype (Chamak \& Mallat 1991, Perry \& Gordon 1991, Giulian et al. 1995, Fujita et al. 1996), although one report maintains that microglial cells do not ramify when serum is absent (Wilms et al. 1997). Components of the extracellular matrix also seem to affect the ramification of microglial cells: laminin inhibits the appearance of the ramified morphology (Chamak \& Mallat 1991, Giulian et al. 1995), while fibronectin promotes (Chamak \& Mallat 1991) or has no clear effects on it (Giulian et al. 1995). Other treatments also promote microglial ramification in vitro, as occurs in media with dimethylsulfoxide, retinoic acid (Giulian \& Baker 1986), granulocyte/macrophage-colony stimulating factor (Fujita et al. 1996), and activated astrocyte culture supernatant (Suzumura et al. 1991). Astrocytes appear to play an important role in determining the mature microglial phenotype, since the coculturing of microglial cells with astrocytes consistently yields high numbers of ramified microglia (Tanaka \& Maeda 1996, Kloss et al. 1997, Tanaka et al. 1999).

The above observations were performed in vitro but may provide some insights applicable to the in vivo situation. They strongly suggest that the differentiated state of microglial cells depends on their environment. For example, the influence of serum on microglial ramification has been used to explain why microglial cells in CNS regions that lack a complete blood-brain barrier (which would preclude the interaction with serum proteins) are less ramified than in other regions of the nervous parenchyma (Perry \& Gordon 1991). It has also been stated that ameboid microglial cells appear mainly in white matter regions of the developing brain, whereas microglial cells in neighboring developing gray matter regions are ramified (Cuadros et al. 1994, 1997). Another consequence of the environmental control of microglia differentiation is the influence of astrocytes and their released products on the differentiation of microglial cells, which would in part explain why fully ramified microglial cells do not appear until advanced stages of development, when astrocytes are also well- developed.

\section{REFERENCES}

Abd-El-Basset A \& Fedoroff S 1995. Effect of bacterial wall lipopolysaccharide (LPS) on morphology, motility, and cytoskeletal organization of microglia in cultures. J Neurosci Res 41: 222-237.

AsHWELL K 1989. Development of microglia in the albino rabbit retina. J Comp Neurol 287: 286-301.

Ashwell K 1990. Microglia and cell death in the developing mouse cerebellum. Dev Brain Res 55: 219230 .

Ashwell K 1991. The distribution of microglia and cell death in the fetal rat forebrain. Dev Brain Res 58: $1-12$. 
AshWell KWS \& Bobryshev YV 1996. The developmental role of microglia. In: LING EA, TAN CK \& TAN CBC, editors. Topical Issues in Microglial Research. Singapore: Singapore Neuroscience Association, pp 65-82.

Ashwell KWS, Holländer H, Streit W \& Stone J 1989. The appearance and distribution of microglia in the developing retina of the rat. Vis Neurosci 2: 437-448.

Badie B, Schartner J, Klaver J \& Vorpahl J 1999. In vitro modulation of microglia motility by glioma cells is mediated by hepatocyte growth factor scatter factor. Neurosurgery 44: 1077-1082.

Berezovskaya O, Maysinger D \& Fedoroff S 1995. The hematopoietic cytokine, colony-stimulating factor 1 , is also a growth factor in the CNS: congenital absence of CSF-1 in mice results in abnormal microglial response and increased neuron vulnerability to injury. Int J Dev Neurosci 13: 285-299.

Blevins G \& Fedoroff S 1995. Microglia in colonystimulating factor-1 deficient op/op mice. J Neurosci Res 40: 535-544.

Bоотн PL \& Thomas WE 1991. Evidence for motility and pinocytosis in ramified microglia in tissue culture. Brain Res 548: 163-171.

Boya J, Calvo J \& Prado A 1979. The origin of microglial cells. J Anat 129: 177-186.

Boya J, Calvo JL, Carbonell AL \& Borregon A 1991. A lectin histochemistry study on the development of rat microglial cells. J Anat 175: 229-236.

Brockhaus J, Möller T \& Kettenmann H 1996. Phagocytozing ameboid microglial cells studied in a mouse corpus callosum slice preparation. Glia 16: 81-90.

Chamak B \& Mallat M 1991. Fibronectin and laminin regulate the in vitro differentiation of microglial cells. Neuroscience 45: 513-527.

Cross AK \& Woodroofe MN 1999. Chemokines induce migration and changes in actin polymerization in adult rat brain microglia and a human fetal microglial cell line in vitro. J Neurosci Res 55: 17-23.

Cuadros MA \& Navascués J 1998. The origin and dif- ferentiation of microglial cells during development. Prog Neurobiol 56: 173-189.

Cuadros MA, Moujahid A, Quesada A \& Navascués J 1994. Development of microglia in the quail optic tectum. J Comp Neurol 348: 207-224.

Cuadros MA, Rodríguez-Ruiz J, Calvente R, Almendros A, Marín-TeVa JL \& Navascués J 1997. Microglia development in the quail cerebellum. $J$ Comp Neurol 389: 390-401.

Dalmau I 1997. Las células de microglía en el cerebro de la rata en desarrollo. Doctoral Thesis. Universidad Autónoma de Barcelona, Barcelona, Spain.

Diaz-Araya CM, Provis JM \& Penfold PL 1995a. Ontogeny and cellular expression of MHC and leucocyte antigens in human retina. Glia 15: $458-470$.

Diaz-Araya CM, Provis JM, Penfold PL \& Billson FA 1995b. Development of microglial topography in human retina. J Comp Neurol 363: 53-68.

Egensperger R, Maslim J, Bisti S, Holländer H \& STONE J 1996. Fate of DNA from retinal cells dying during development: uptake by microglia and macroglia (Müller cells). Dev Brain Res 97: 1-8.

Elkabes S, Diciccobloom EM \& Black IB 1996. Brain microglia macrophages express neurotrophins that selectively regulate microglial proliferation and function. J Neurosci 16: 2508-2521.

Fedoroff S 1995. Development of microglia. In: KeTTENMANN H \& RANSOM BR, editors. Neuroglia. New York: Oxford University Press, pp 162-181.

Fedoroff S, Zhai R \& Novak JP 1997. Microglia and astroglia have a common progenitor cell. J Neurosci Res 50: 477-486.

Ferrer I, Bernet E, Soriano E, Del Rio T \& Fonseca M 1990. Naturally occurring cell death in the cerebral cortex of the rat and removal of dead cells by transitory phagocytes. Neuroscience 39: 451-458.

Flaris NA, Densmore TL, Molleston MC \& Hickey WF 1993. Characterization of microglia and macrophages in the central nervous system of rats: definition of the differential expression of molecules using standard and novel monoclonal antibodies in normal CNS and in four models of parenchymal reaction. 
Glia 7: 34-40.

Fujita H, Tanaka J, Toku K, Tateishi N, Suzuki Y, Matsuda S, Sakanaka M \& Maeda N 1996. Effects of GM-CSF and ordinary supplements on the ramification of microglia in culture: a morphometrical study. Glia 18: 269-281.

Fujita H, Tanaka J, Maeda N \& Sakanaka M 1998. Adrenergic agonists suppress the proliferation of microglia through beta 2-adrenergic receptor. Neurosci Lett 242: 37-40.

Ganter S, Northoff H, Männel P \& GebickeHÄrTER PJ 1992. Growth control of cultured microglia. J Neurosci Res 33: 218-230.

Garcia-Valenzuela E \& Sharma SC 1999. Laminar restriction of retinal macrophagic response to optic nerve axotomy in the rat. J Neurobiol 40: 55-66.

Gehrmann J, Matsumoto Y \& Kreutzberg GW 1995. Microglia: intrinsic immunoeffector cell of the brain. Brain Res Rev 20: 269-287.

GiUlian D \& BaKer TJ 1986. Characterization of ameboid microglia isolated from developing mammalian brain. J Neurosci 6: 2163-2178.

Giulian D \& Ingemann JE 1988. Colony-stimulating factors as promoters of ameboid microglia. $\mathrm{J} \mathrm{Neu}$ rosci 8: 4707-4717.

Giulian D, Johnson B, Krebs JF, George JK \& TAPscott M 1991. Microglial mitogens are produced in the developing and injured mammalian brain. J Cell Biol 112: 323-333.

Giulian D, Bartel S, Broker J, Li X \& Kirkpatrick JB 1995. Cell surface morphology identifies microglia as a distinct class of mononuclear phagocyte. J Neurosci 15: 7712-7726.

Glabinski AR, Balasingam V, Tani M, Kunkel SL, Strieter RM, Yong VW \& Ransohoff RM 1996. Chemokine monocyte chemoattractant protein- 1 is expressed by astrocytes after mechanical injury to the brain. J Immunol 156: 4363-4368.

HaApaniemi H, Tomita M, Tanahashi N, Takeda H, Yокоуама M \& FukuUchi Y 1995. Nonamoeboid locomotion of cultured microglia obtained from newborn rat brain. Neurosci Lett 193:
121-124.

HaLfTER W \& Fua CS 1987. Immunohistochemical localization of laminin, neural cell adhesion molecule, collagen type IV and T-61 antigen in the embryonic retina of the japanese quail by in vivo injection of antibodies. Cell Tiss Res 249: 487-496.

Halfter W, Reckhaus W \& Kröger S 1987. Nondirected axonal growth on basal lamina from avian embryonic neural retina. J Neurosci 7: 3712-3722.

Hao C, Richardson A \& Fedoroff S 1991. Macrophage-like cells originate from neuroepithelium in culture: characterization and properties of the macrophage-like cells. Int J Dev Neurosci 9: 1-14.

Hume DA, Perry VH \& Gordon S 1983. Immunohistochemical localization of a macrophage-specific antigen in developing mouse retina: phagocytosis of dying neurons and differentiation of microglial cells to form a regular array in the plexiform layers. $J$ Cell Biol 97: 253-257.

Imamoto K \& Leblond CP 1978. Radioautographic investigation of gliogenesis in the corpus callosum of young rats. II. Origin of microglial cells. J Comp Neurol 180: 134-164.

Ivacko J, Szaflarski J, Malinak C, Flory C, WarREN JS \& Silverstein FS 1997. Hypoxic-ischemic injury induces monocyte chemoattractant protein-1 expression in neonatal rat brain. J Cereb Blood Flow Metab 17: 759-770.

KAUR C \& LiNG EA 1991. Study of the transformation of amoeboid microglial cells into microglia labelled with the isolectin Griffonia simplicifolia in postnatal rats. Acta Anat 142: 118-125.

Kitamura T, Miyake T \& Fujita S 1984. Genesis of resting microglia in the gray matter of mouse hippocampus. J Comp Neurol 226: 421-433.

Kloss CUA, Kreutzberg GW \& Raivich G 1997. Proliferation of ramified microglia on an astrocyte monolayer: characterization of stimulatory and inhibitory cytokines. J Neurosci Res 49: 248-254.

Lawson LJ, Perry VH, Dri P \& Gordon S 1990. Heterogeneity in the distribution and morphology of microglia in the normal adult mouse brain. Neuro- 
science, 39: 151-170.

Lawson LJ, Perry VH \& Gordon S 1992. Turnover of resident microglia in the normal adult mouse brain. Neuroscience 48: 405-415.

LeE S, Liu W, Brosnan C \& Dickson D 1994. GMCSF promotes proliferation of human fetal and adult microglia in primary cultures. Glia 12: 309-318.

LING EA 1976. Some aspects of amoeboid microglia in the corpus callosum and neighbouring regions of neonatal rats. J Anat 121: 29-45.

LING EA 1981. The origin and nature of microglia. In: Fedoroff S, Hertz L, editors. Advances in Cellular Neurobiology, Vol. 2. London: Academic Press, pp 33-82.

LING EA \& TAN CK 1974. Ameboid microglia cells in the corpus callosum of neonatal rats. Arch Histol Jap 36: $265-280$.

LING EA \& Wong WC 1993. The origin and nature of ramified and amoeboid microglia: a historical review and current concepts. Glia 7: 9-18.

Ling EA, Penney D \& Leblond CP 1980. Use of carbon labelling to demonstrate the role of blood monocytes as precursors of the "amoeboid cells" present in the corpus callosum of postnatal rats. J Comp Neurol 193: $631-657$.

Liva SM, Kahn MA, Dopp JM \& DE Vellis J 1999. Signal transduction pathways induced by GM-CSF in microglia: significance in the control of proliferation. Glia 26: 344-352.

López-García C, Nacher J, Castellano B, Luis de LA Iglesia JA \& Molowny A 1994. Transitory disappearance of microglia during the regeneration of the lizard medial cortex. Glia 12: 52-61.

Maciejewski-Lenoir D, Chen SZ, Feng LL, MaKi R \& BACON KB 1999. Characterization of fractalkine in rat brain cells: migratory and activation signals for CX3CR-1-expressing microglia. J Immunol 163: 1628-1635.

Mallat M, Calvo CF \& Dobbertin A 1996. Recruitment of brain macrophages: roles of cytokines and extracellular matrix proteins produced by glial or neuronal cells. Braz. J. Med. Biol. Res. 29:
1173-1177.

Marín-Teva JL, Almendros A, Calvente R, Cuadros MA \& NAVASCuÉs J 1998. Tangential migration of ameboid microglia in the developing quail retina: mechanism of migration and migratory behavior. Glia 22: 31-53.

Marín-Teva JL, Almendros A, Calvente R, Cuadros MA \& NAvAscuÉs J 1999a. Proliferation of actively migrating ameboid microglia in the developing quail retina. Anat Embryol 200: 289-300.

Marín-Teva JL, Calvente R, Cuadros MA, AlmenDros A \& Navascués J 1999b. Circumferential migration of ameboid microglia in the margin of the developing quail retina. Glia 27: 226-238.

Marín-Teva JL, Cuadros MA, Calvente R, AlmenDROS A \& NAVAsCuÉs J 1999c. Naturally occurring cell death and migration of microglial precursors in the quail retina during normal development. J Comp Neurol 412: 255-275.

Milligan CE, Cunningham TJ \& Levitt P 1991. Differential immunochemical markers reveal the normal distribution of brain macrophages and microglia in the developing rat brain. J Comp Neurol 314: 125135 .

Moujahid A, Navascués J, Marín-Teva JL \& Cuadros MA 1996. Macrophages during avian optic nerve development: relationship to cell death and differentiation into microglia. Anat Embryol 193: 131144 .

Murabe Y \& SAno Y 1982. Morphological studies on neuroglia. VI. Postnatal development of microglial cells. Cell Tiss Res 225: 469-485.

Navascués J, Moujahid A, Almendros A, MarínTeva JL \& CuAdros MA 1995. Origin of microglia in the quail retina: central-to-peripheral and vitrealto-scleral migration of microglial precursors during development. J Comp Neurol 354: 209-228.

Navascués J, Cuadros MA \& Almendros A 1996. Development of microglia: evidence from studies in the avian central nervous system. In: LING EA, TAN CK \& TAN CBC, editors. Topical Issues in Microglia Research. Singapore: Singapore Neuroscience Association, pp 43-64. 
Pearson He, Payne BR \& Cunningham TJ 1993. Microglial invasion and activation in response to naturally occurring neuronal degeneration in the ganglion cell layer of the postnatal cat retina. Dev Brain Res 76: $249-255$.

PERRY VH 1987. Macrophages, microglia and cell death in the developing mouse brain. Pontif Acad Scient Scripta Varia 59: 281-295.

Perry VH \& Gordon S 1991. Macrophages and the nervous system. Int Rev Cytol 125: 203-244.

Perry VH \& Lawson LJ 1992. Macrophages in the Central Nervous System. In: LewIS EC \& McGeE JOD, editors. The Macrophage. Oxford: IRL Press, pp 389-413.

Perry VH, Hume DA \& Gordon S 1985. Immunohistochemical localization of macrophages and microglia in the adult and developing mouse brain. Neuroscience 15: 313-326.

Raivich G, Moreno-Flores MT, Möller JC \& KreutzBerg GW 1994. Inhibition of posttraumatic microglial proliferation in a genetic model of macrophage colony-stimulating factor deficiency in the mouse. Eur J Neurosci 6: 1615-1618.

RAKIC S \& ZECEVIC N 1998. Apoptosis and microglia in the fetal human brain. Soc Neurosci Abst 24: 807.

Rio-Hortega P 1932. Microglia. In: Penfield W, editor. Cytology and Cellular Pathology of the Nervous System, Vol. 2. New York: Paul B. Hoeber, pp 481-534.

Ringheim GE 1995. Mitogenic effects of interleukin-5 on microglia. Neurosci Lett 201: 131-134.

Sawada M, Suzumura A, Yamamoto H \& MaruNOUCHI T 1990. Activation and proliferation of the isolated microglia by colony stimulating factor- 1 and possible involvement of protein kinase C. Brain Res 509: 119-124.

SCHNitzer J 1989. Enzyme-histochemical demonstration of microglial cells in the adult and postnatal rabbit retina. J Comp Neurol 282: 249-263.

Shafit-Zagardo B, Sharma N, Berman JW, BornSTEIN MB \& BROSNAN CF 1993. CSF-1 expression is upregulated in astrocyte cultures by IL-1 and TNF and affects microglial proliferation and morphology in organotypic cultures. Int J Dev Neurosci 11: 189198.

Stewart PA \& Wiley MJ 1981. Structural and histochemical features of the avian blood-brain barrier. $J$ Comp Neurol 202: 157-167.

Stoll G \& JANDER S 1999. The role of microglia and macrophages in the pathophysiology of the CNS. Prog Neurobiol 58: 233-247.

Streit WJ, Graeber MB \& Kreutzberg GW 1988. Functional plasticity of microglia: a review. Glia 1: 301- 307.

Sugita Y, Becerra SP, Chader GJ \& Schwartz JP 1997. Pigment epithelium-derived factor (PEDF) has direct effects on the metabolism and proliferation of microglia and indirect effects on astrocytes. $J$ Neurosci Res 49: 710-718.

Suzumura A \& Sawada M 1996. Microglia as immunoregulatory cells in the central nervous system. In: LING EA, TAN CK \& TAN CBC, editors. Topical Issues in Microglia Research. Singapore: Singapore Neuroscience Association, pp 189-202.

Suzumura A, Sawada M, Yamamoto H \& MaruNOUCHI T 1990. Effects of colony stimulating factors on isolated microglia in vitro. J Neuroimmunol 30: $111-120$.

Suzumura A, Marunouchi T \& Yamamoto H 1991. Morphological transformation of microglia in vitro. Brain Res 545: 301-306.

Suzumura A, Sawada M, Itoh Y \& Marunouchi T 1994. Interleukin-4 induces proliferation and activation of microglia but suppresses their induction of class II major histocompatibility complex antigen expression. J Neuroimmunol 53: 209-218.

TANAKa J \& MAeda N 1996. Microglial ramification requires nondiffusible factors derived from astrocytes. Exp Neurol 137: 367-375.

Tanaka J, Toku K, Sakanaka M \& Maeda N 1999. Morphological differentiation of microglial cells in culture: involvement of insoluble factors derived from astrocytes. Neurosci Res 34: 207-215.

Thanos S 1991. The relationship of microglial cells to 
dying neurons during natural neuronal cell death and axotomy-induced degeneration of the rat retina. Eur J Neurosci 3: 1189-1207.

Thanos S, Moore S \& Hong Y 1996. Retinal microglia. Progr Ret Eye Res 15: 331-361.

Vela-Hernández JM, Dalmau I, González B \& Castellano B 1997. Abnormal expression of the proliferating cell nuclear antigen (PCNA) in the spinal cord of the hypomyelinated jimpy mutant mice. Brain Res 747: 130-139.

Ward SA, Ransom PA, Booth PL \& Thomas WE 1991. Characterization of ramified microglia in tissue culture: pinocytosis and motility. J Neurosci Res 29: $13-28$.

Wilms H, Hartmann D \& Sievers J 1997. Ramification of microglia, monocytes and macrophages in vitro: influences of various epithelia and mesenchymal cells and their conditioned media. Cell Tiss Res 287: 447458.

Wilms H, Wollmer MA \& Sievers J 1999. In-vitro staining specificity of the antibody 5-D-4 for microglia but not for monocytes and macrophages indicates that microglia are a unique subgroup of the myelomonocytic lineage. J Neuroimmunol 98: 8995.
WoLSWIJK G 1995. Strongly GD3+ cells in the developing and adult rat cerebellum belong to the microglial lineage rather than to the oligodendrocyte lineage. Glia 13: 13-26.

Wong ROL, Hughes A 1987. Role of cell death in the topogenesis of neuronal distributions in the developing cat retinal ganglion cell layer. J Comp Neurol 262: 496-511.

Wu CH, Wen CY, Shieh JY \& Ling EA 1996. Use of lectin as a tool for the study of microglial cells: expression and regulation of lectin receptors in normal development and under experimental conditions. In: LING EA, TAN CK \& TAN CBC, editors. Topical Issues in Microglia Research. Singapore: Singapore Neuroscience Association, pp 83-202.

Xu J, Kaur C \& Ling EA 1993. Variation with age in the labelling of ameboid microglial cells in rats following intraperitoneal or intravenous injection of a fluorescent dye. J Anat 182: 55-63. 